\title{
IMPROVED CONTRRUST ANTICORROSION AGENT - AN INNOVATIVE TOOL FOR TECHNOLOGICAL PROGRESS, ECONOMICS END ENVIRONMENT PROTECTION
}

\author{
Savenko V. I., Polosenko O. V.
}

\section{INTRODUCTION}

The enormous cost of replacing or restoring corroded metal parts, machinery and equipment parts, structures of buildings and consumer goods drives humanity to seek corrosion protection. Research and experience in the long-term operation of metal products show that the most important factor in protecting and preventing corrosion is the reliable and correct preparation of metal surfaces for painting. It is easier and more reliable to prevent the corrosion process than to stop and repair the affected parts and products. Applying innovations, research and development with the appropriate support of government and society can benefit the economy and the environment.

The study of the types of corrosion and the processes that are tested at the beginning and during the corrosion of metals to find reliable reagents for damping corrosion micro sources and create a reliable film (protective layer) on the surface before painting under which it is impossible to start corrosion under the protective layer. Saving metal-based objects through the effective use of innovative technologies is a very important issue, but equally important is the creation of conditions and the support for innovation activity that creates innovation.

Many studies of corrosion processes and the arrangement of protective coatings are known. There are also many substances for cleaning surfaces, inhibitors, sprays, impurities, etc. Ecologically safe, effective means of plant origin are not presented. There is already a patented CONTRRUST converter Patent No. (11) 61544, by L. Vysotska ${ }^{1}$. But the technology of its application and market promotion is still quite slow Several monographs and dozens of articles have been published on the topic of the use of the CONTRRUST ecomodifier by authors (V.I. Savenko, V.M. Vashenko, L.M. Vysotska, A.A. Plugin, O.A. Mashkov, I.V. Kushchenko, V.P. Korolev, O.D. Zhuravsky, A.M. Korotiev, D.Ya. Kislyuk, S.Yu. Maksimov, O.V. Polosenko,

\footnotetext{
${ }^{1}$ Rust Converter KONTRRUST : Patent 61544 № 11 Ukraine.
} 
V.V. Klyueva and many others $)^{2}$, many reports were made at international conferences, the work was marked by many awards, certificates, but as noted in the works of another plan (Y.F. Shkvorets, Ron Hubbard, P.Y. Kalyta, V.I. Savenko, A.I. Prigogine, etc.) it is very important that Rennes favorable conditions and support innovation by the government and society, while the invention and innovation are the driving force of progress.

\section{Section research and testing of environmentally friendly material to solve metal corrosion problems}

Promotion of the CONTRRAST rust converter and the spread of new technologies for protection of metals from corrosion in an environmentally friendly way, a way of preventing the start of corrosion processes with subsequent protective surface painting. Advanced science, high technology, education and staff development and the creation of the genome of business and spiritual excellence can ensure the company leadership in production and society. Currently the losses from corrosion in industrialized countries reach up to 3-5 per cent from the national income. It mainly concerns metallurgic and chemical enterprises, oil and gas pipelines, and floating crafts, which elements and structures operate in a highly corrosive environment. He inner surface of cargo compartments, liquid ballast tanks, fuel supplies, pipelines and other structures are subject to severe corrosion under the influence of seawater and oil products with a high level of sulfur.

The carcass of reinforced concrete structures is of great significance since it takes in the pulling stress from the external load, providing the stability of the construction.

Therefore, carcass corrosion is inadmissible. It leads to destructing the adhesion between the concrete and carcass, cracking and delaminating the protective concrete layer; moreover, it results in pre-stress losses in prestressed elements, which causes the destruction of buildings and structures.

The total damage of corrosion sums up to billions of dollars because of emergencies and ecological disasters. It is quite difficult to calculate all the losses from standstills and production decline of the equipment that is subject to corrosion, the disruption of technological processes, accidents caused by the stability decrease of metal structures, the environment pollution, payment of insurance benefits, and, finally, lethal outcomes.

The presence of oxygen and water on the surface of iron products results in creating iron oxides and hydroxides, which in everyday life is called rust.

\footnotetext{
2 Забезпечення корозійної та функціональної стійкості металомістких комплексів і критичної інфраструктури за допомогою інноваційних науковомістких екоресурсозберігаючих технологій : монографія / В.І. Савенко, А.А. Плугін, І.В. Кущенко, Л.М. Висоцька та ін. Київ : УАН. Центр учбової літератури, 2019. 306 с.
} 
Rust ends up in water mostly in the form of colloidal particles, but there can alsobe bigger particles (incrustations) - an oxide mixture.

The corrosion of water lines leads to the biological contamination of water, which poses a potential threat to our health.

The Committee of Maritime security imposed a new requirement on the availability of corrosion protection systems in source water tanks, which are the most effective methods in any defect repair during the operation process examination.

A rust modifier "Contrrust" has been invented by specialists and the PC "Ruslan and Lyudmila" authoring team. It has been developed as the main preventive tool for surfaces that are damaged by rust; it penetrates into the metal shell on a molecular level, blocks the rust within it, protects the surface from further rusting processes without damaging its structure.

"Contrust" is a universal, ecologically sound, plant-based anti-rust agent that al-Lows us to eliminate corrosion during the construction, and operation process of metal constructions.

The whole range of redox reactions results in creating a black with blue shimmer metal polymer foil with the thickness of 30-50 um, the adhesion.of 1 point (ISO 4618: 2014) ${ }^{3}$ and impact index $50 \mathrm{~cm}$ (ISO $\left.8501-1: 1988\right)^{4}$ on the surface of the deoxidized metal.

The transformative technology of "Contrust" with an average thickness of rust within $300 \mathrm{um}$ results in 100 per cent of purity.

"Contrrust" - an ultimate protection against corrosion. "CONTRRUST" - rust modifier, protective primer of high efficiency, nontoxic, environmentally safe. One component. The main components which make up the "Contrrust" are: tanning extracts, succinic, citric, oxalic acid and other food acids, water. Fabricated in three modifications:

a) liquid;

b) viscous substance;

c) powder.

Does not contain any toxic elements such as lead or zinc chromate, phosphate acid, safe for human life and health during its manufacture and use. Not flammable. Easy to use.

Can be used in hardly-accessed areas of any configuration. Replaces corrosion removal, and serves as the primer layer. Replaces interim working primer. Positive effect on the welding.

Restores and protects surface. Should be applied to tenacious layer of iron scale.

Has good diffusion. Blocks centers of corrosion in metal shells. Dries quickly. No need to too wash off the surface.

${ }^{3}$ ISO 4618: 2014. Paints and varnishes. Terms und definitions. P. 1-3.

${ }^{4}$ Международный стандарт ISO 8501-1: 1988. Р. 1-4. 
Converts rust of 100-300 microns thick into protective anticorrosive film-primer, which blocks the surface from repeated corrosion over time. Product consumption: $40-80 \mathrm{ml} / \mathrm{m}^{2}$. Economic effect reaches $60 \%$.

Table 1

Specifications

\begin{tabular}{|l|l|}
\hline Appearance & Liquid \\
\hline Color & Brown \\
\hline Smell & nice (dried fruit ) \\
\hline density & $1,07-1,12 \mathrm{~g} / \mathrm{cm} 3$ \\
\hline $\mathrm{pH}$ & $0,5-3$ \\
\hline freezing temperature of & $-5^{\circ} \mathrm{C}$ \\
\hline drying time at temperature $(20 \pm 2)^{\circ} \mathrm{C}$ & $1-2 \mathrm{~h}$ \\
\hline After-treatment color & dark-blue \\
\hline $\begin{array}{l}\text { Thickness of iron salts after the modification of the } \\
\text { rust layer on a steel surface }\end{array}$ & $30-50$ microns \\
\hline Adhesion Paint & 2 points \\
\hline $\begin{array}{l}\text { Resistance of the converted rust layer on the } \\
\text { modified surface to the statistical effects of water, } \\
\text { crude oil, petroleum products at a temperature of } \\
(20 \pm 2)^{\circ} \mathrm{C}\end{array}$ & at least 72 hours \\
\hline
\end{tabular}

\section{Advantages and anticorrosion protection}

A rust converter with excellent penetrating ability and is used as a universal primer (preservative, inter-op prime coating without disturbing the surface roughness) and provisional coating (first prime coat layer) with good adhesion up to minimally prepared surface and for repair of old coats as well as for strengthening of a dross to the metal surface.

Blocks corrosion centers in metal surface holes, dries quickly, doesn't need washing down thereof from a metal surface, quickens a technological process of metal surface coating and increases terms of exploitation of exploitation of metal constructions without decreasing a normative exploitation in different environments according to the requirements of ISO $12944^{5}$.

Provides with a reliable adhesion strength relative to lacquer and insulation coatings.

"Contrrust" substitutes sandblast, mechanical surface cleaning (local places, welding seams are cleaned), it is recommended for processing of rust

${ }^{5}$ Международный стандарт ЛАКИ и КРАСКИ. 18 с. 
damaged surfaces metal constructions and in cases when mechanical or sandblast cleaning is complicated or economically inexpedient.

Drying within 20-30 min. Under normal conditions, it forms dark-blue or black layer which is complicated ferric/ferric acid organic compounding, which provides with anti-corrosion protection. Protective layer may be used as a primer under different lacquer and insulation materials.

- The application of rust converter "Contrrust" allowed is surface painting $3^{\text {rd }}-4$ th level of cleaning from oxides with application of technological schemes of surface preparation 19, 23, 24 Table 4, under GOST 9.402-2004 ${ }^{6}$.

If the technological process requires a preparation of a surface for SA 2,5 and other, the rust converter "Contrrust" is applied to blocking the corrosion centers which appear due to oxygen and moisture joining;

- Increasing the life of the coated system by 2-4 times (in closed spaces - in 6-9 times), and even longer - for other types of coatings;

- Reduction of labor costs, the cost and timing of metal-construction works by $50-70 \%$;

- Complete safety and ease of use in any way (by brush, roller or spray, syringe, etc.) - use without respirators and expensive arsenal of tools and accessories;

- Indispensable in the treatment of metal structures of particularly complex configuration (from seaport facilities to underground and above ground pipelines);

- Blocks and suppresses hidden deep corrosion - due to high diffusivity and organic components;

- Surface quality is maintained for many months (in an enclosed space - more than a year!) - With the normative requirements of GOST of Ukraine $9402-2004^{7}$ only "24 hours".

"Contrrust" is used at any time of the year for the treatment of steel pipes, cable sheath, roofs, reinforcing mesh, nodes pairing, tanks, reservoirs, pipelines, metal structures in mines, power plants and at nuclear power plants in the service station, ship repair and building, railway works, underground constructions, food processing equipment, to detect corrosion cells in pressure vessels and structures of special products, in particular stainless, as well as micro-cracks and pitting during the manufacture of steel materials for special purposes and in many sectors of the economy, in closed inaccessible spaces on stationary and moving civilian and military objects (bulkhead ballast tanks, holds, submarines, tankers, tanks, armored vehicles,

\footnotetext{
6 ГОСТ 9.402-2004. Единая система защиты от коррозии. Москва : Стандартинформ. С. 3-5.

ГОСТ 9.402-2004 Единая система защиты от коррозии. Москва : Стандартинформ. С. 10-12.
} 
tanks for drinking water and food storage, vehicles, on the valve of sandwich panels, ventilated facades, walls and new type roofings, etc.).

Can be used to isolation of steel and concrete structures in accordance with the requirements of EN 1504-7 "Products and systems for the protection and repair of concrete structures - Definitions, requirements, quality control and evaluation of conformity - Part $7^{8}$ : Reinforcement corrosion protection".

As a result of the tests it was found that the treatment of reinforcing bars by the anticorrosion tool "Contrrust" does not impair the adhesion of the reinforcement with concrete.

As a result of tests of prototypes, efforts were obtained in which the rebar rods (PG brand) were pulled out and the prisms were split into two parts (PP brand). The test results are shown.

Test results of test samples of GHG and PP brand

No. $\mathrm{p}$ / $\mathrm{n}$ Sample mark Stripping or splitting force, $\mathrm{kN}$ Notes one sample average

$1 \mathrm{PG}$ - (core) - 124.0023 .38 retraction of reinforcing rods

$2 \mathrm{GH}-$ (cor) -222.50

$3 \mathrm{NG}-($ cor $)-323.25$

$4 \mathrm{PG}-$ (cor) -423.75

$5 \mathrm{PG}-$ (core + Contrrust) -122.5023 .39 retraction of reinforcing rods

$6 \mathrm{PG}-(\mathrm{Cor}+$ Contrrust $)-224.50$

$7 \mathrm{PG}-($ cor + Contrrust $)-323.80$

$8 \mathrm{PG}-($ cor + Contrrust $)-422.75$

$9 \mathrm{PP}$ - (cor) - 129.5029 .88 splitting prisms into two parts

$10 \mathrm{PP}-(\mathrm{cor})-231.25$

$11 \mathrm{PP}-($ cor $)-328.75$

$12 \mathrm{PP}-(\mathrm{cor})-430.00$

$13 \mathrm{PP}-($ cor + Contrrust $)-130.7530 .08$ splitting prisms into two parts

$14 \mathrm{PP}-($ cor + Contrrust $)-228.25$

$15 \mathrm{PP}-($ cor + Contrrust $)-329.80$

$16 \mathrm{PP}-($ cor + Contrrust $)-431.50$

Analysis of the test results showed that in the specimens with smooth reinforcement, the rebar of the concrete prism was pulled out. The mean force at which the rebar rods were pulled out for samples with untreated and treated anti-corrosion agent Contrrust was respectively $23.38 \mathrm{kN}$ and $23.39 \mathrm{kN}$. In specimens with ribbed reinforcement, the destruction of concrete prisms (splitting into two parts) occurred. The average force at which concrete prisms were split for samples with untreated and treated anticorrosion agent Contrrust was respectively $29.88 \mathrm{kN}$ and $30.08 \mathrm{kN}$.

${ }^{8}$ BS EN 1504-7 2006. Products and systems for the protection. Part 7. 
Before applying the "Contrrust" the surface needs to be cleaned from grease, dirt, ill keep paints, primers, isolation. Formation and loose rust is to be removed with a metal brush, and wiped with a damp cloth.

"Contrrust" is applied to dry or wet surface with a continuous uniform layer without streaks in any convenient way: brush, roller, means towels, airless spray, etc.

After applying the rust converter it does NOT need to be rinsed or cleaned, and after drying the coating can be directly applied in accordance with needed coating requirements.

For example:

When repairing a vehicle (body, bottom and in other accessible places) use a metal brush to clean the surface and an emery paper to polish the surface, thus, the surface should remain only with the "noble" rust, that is "red rust".

Passages and channels in the hardly available spaces are to be cleaned by any sharp tool (a thin knife, etc.). Fatty place should be degreased. Other dismounted parts of the car (caliper, metal disk, etc.) should be heated to $+16+35^{\circ} \mathrm{C}$ (heat from sun shown might be enough) and treated with "Contrrust".

Having assured that the surface is dried up and no rust spots remain on the surface (and if there are still present - should be treated with rustconverter locally - the primer should be applied (sealer, insulation), in hardly accessible places - should be splashed inside. For the treatment of the inner surface of the car through the hole thresholds introduce a rubber tube to the end of the threshold, pour a rust converter, gradually pulling the tube out.

At negative temperatures, the process of applying rust-converter is recommended to be supported by adding alcohol or warming the surface itself.

The warranty period for the "Contrust" protection applied according to the manufacturer's instructions is no less than the warranty period of the paint coating that will be applied on the surface after treatment with "Contrrust" (including coatings that can withstand temperatures above $300{ }^{\circ} \mathrm{C}$ ) In all cases, we recommend using coatings or paint after treatment by "Contrrust".

"CONTRRUST" modification "B" (powder, which can be prepared under extreme conditions for modification " $A$ ") allows elimination of point and gap corrosion in the course of metalwork.

"CONTRRUST" (CR) provides for high-quality surface treatment preceding final coating. $\mathrm{CR}$ can be used in any season to treat steel:

pipes, cable braid, roof tiles, concrete reinforcing mesh, matings, sandwich panels, tanks, main piping before reinforcing, mining metal works, 
electric, nuclear power-generating, automotive and bodyworks, ship building and maintenance (e.g. ballast tanks), railway and subway, food industry (esp for "purity grade" equipment), equipment for production of explosives (with high purity requirement), instruments' hardware, structural steel works with welded add-ins, - between structural elements where micro-cracks tend to appear, where corrosion rate is ten times high than on open surface, it can be used to treat chemical industrial equipment, to treat carrying iron of oil and gas pipelines without interruption. Consult "usage".

\section{Section Using the results obtained and the problems of introducing innovative material and possible ways of solving them}

Before applying CR, dirt, peeling off paint, priming, isolation, scaling and crumbling rust must be cleaned away with a steel brush, and then surface is to be wiped with wet tissues and degreased.

CR is applied upon dry or wet surface in even layer, without streaks, by brush (recommended for seams, bents corners), and or any other simple means such as paint roller, wiping or airless sprayer (must be equipped with chemical industry's grade polyurethane, runner or teflon washers, gaskets, spouts and cups). Method of application has to correspond to the type of corrosion and specific needs. New metalwork's elements are to be treated with CR to modify the corrosion, which has appeared after Sa2.5 surface working and welding seams.

If rust is thicker than 150 microns, or if there are streaks of rust after first coating, the rust spots are to be treated with CR until blue anticorrosive layer-prime appears.

The overall process of metal-polymerization takes about 120 minutes, then the surface is ready for final coatings. If the temperature of treated surface is higher than $+30+35^{\circ} \mathrm{C}$, cold desalinated water is to be used to cool the surface down, the recommended temperature for the procedure is:

$+18 \pm 2{ }^{\circ} \mathrm{C}$. If modifier's film dries up too quick, it has to be whetted with desalinated water to improve the process of metal-polymerization.

It is not recommended to treat exceedingly warm metalwork's elements with CR.

"Dust" may appear upon the surface after the drying; remove it with soft tissue and re-apply coating. If required the isolation may be applied as per metal surfaces' treatment.

If procedure performed outdoors, protect the treated surface against any precipitations, until complete drying-up.

After the modifier has been applied, do not clean or rinse the treated surface; after complete drying-up final coating can be applied in accordance with the coating's specification and requirements. 
If $\mathrm{CR}$ comes upon the surface not meant for further treatment i.e. painting, it has to be wiped off with a wet tissue.

$\mathrm{CR}$ modifier has to be thoroughly stirred before application, as well as strained before use in airless sprayer.

CR consumption varies between 40 to $120 \mathrm{~g}$ per $1 \mathrm{~m}^{2}$

Safety tips.

Use gauze mask, respirators and goggles when applying CR modifies to vertical surfaces with airless sprayer. Use rubber gloves to prevent skin coloration.

If $\mathrm{CR}$ comes into contact with skin, dark spot appears, which can be easily removed with water solution of any natural food acid. If CR comes into eyes, thoroughly rinse with water.

The economic effect of using rust modifier on different objects, structures, and metal structures is currently over UAH 62 million. including:

Kyiv, str. Solomianskaya 2a, customer - Court of Appeal, designer CJSC "GIPROtsivilprombud" - economic effect - 30,0 million UAH;

PJSC "PVI-ZIT Oil and Gas" as a contractor for Kutaisi-Abasha (Georgia) gas pipeline - UAH 10.2 million, Lviv Bobrivka UAH 0.743 million, Brest (Belarus) - UAH 0.739 million;

Lukoil - Karpatnaftochim Company - UAH 6.41 million;

Kharkiv, Sumy market - contractor of LLC Spetsstroymontazh Ukraine - UAH 5.8 million and other.

At the present stage, from the experience of previous years, success can only be achieved with government support in the form of creating favorable conditions for the activities of organizations.

The first step towards achieving a teleonomic level of survival is to bring our activities in line with international standards of the ISO 9001 series, which corresponds to a level of 250-300 points on a 1000-point scale of the EFQM. The second step is the introduction of a model of excellence TQM or EFQM.

That makes it possible to reach the level of $450-500$ points on the EFQM scale, maybe more, but this is with serious scientific and innovative support. Without science and innovation, it is impossible to become a leader. The introduction of even the most advanced models is following the leader.

Completely new paths of development are the paths of scientific discoveries and inventions The future leading position of any company, also a production one, is determined by the ability of leaders and all personnel to master high technology innovations, to generate and quickly implement their inventions and discoveries. The future is for science and inventors. An organization headed by leaders (owners, managers, performers), they created a gene (tradition) of high spiritual and business cultures that organize synergistic controlled actions and control subsystems, formal and informal 
organizational structure of the organization with the mandatory support of the state, properly assessed and timely take into account internal and external factors, are doomed to success.

In the sphere of material production, the "living" labor of people continuously materializes in structures, machines, machines, buildings, etc.

How difficult it is to incorporate new technology into existing production!

An experiment has long appeared and is still being used and its essence is that it makes it possible to test every technical, production and any innovation before finally introducing it. To check, then, is to test it for effectiveness, to determine under what conditions it can be widely implemented, what needs to be changed in it, etc. That is, an experiment is a comprehensive diagnosis of innovation and an important part of the very transitional mechanism, when first a small part of the system, an experimental object, is involved in the innovation process, on which the innovation is developed to a replicable state and only then it is distributed to other objects. At the same time, an experiment is a study of action with all the signs and capabilities of such a study.

There are two main reasons for resorting to experiments in technology and production:

- overcoming resistance to changes, since the stage of the experiment facilitates their implementation;

- reduction of risk from unforeseen consequences of radical decisions.

The experiment is a trial innovation. Its purpose is to provide a basis for deciding whether to accept this innovation for implementation and distribution or not. If so, with what changes, restrictions, under what conditions. It is a decision that is the result of the experiment. It is incorrect to call an experiment unsuccessful only on the grounds that, as a result, it was decided not to spread the tested innovation. A negative result is also valuable here, since the proof closes the path to one of the proposed options, thereby protecting against error. There are different types of experiments. The foregoing refers to the field or field version of an experiment conducted on real objects. He is the most visual, convincing. Maybe that's why it is so widespread.

In practice, in production, and in large-scale scientific research, experiment is a complex and, in some conditions, expensive tool, which, however, has good development prospects. Moreover, in modern conditions the possibilities of non-experimental changes are limited, and the need for lowering the threshold of unforeseenness, in forecasting development paths is increasing.

The transition to a higher level of field production experimentation, that is, to the decisive experiment, means the inclusion of the choice of options in 
it, the search for the solution to the problem itself. Such development of the experiment would significantly change its social status, increase its responsibility.

The diagnostic function of an experiment is to identify the problems of implementing an innovation, that is, evaluating an innovation for its feasibility and "viability". This means determining the degree of adequacy of the innovation to the environment of its implementation, the possibility of implementing the innovation process or the correspondence of the expected result of the implementation of the innovation (including unplanned, secondary) with goals of a wider order for which the innovation is being designed. These estimates may diverge. The concepts of "feasibility" and "efficiency" in innovation are by no means identical, because the quick and complete completion of an innovation does not exclude its negative effect.

The diagnostic function of an innovative experiment is not limited to the evaluative side only. It also involves the development of innovation, that is, the determination of the directions of its changes both in the content of the tested innovation and in the methods for its implementation. These changes should ensure the feasibility of the innovation and its relevance to more general goals. An innovative experiment paired with a cognitive one is possible both at the level of theoretical understanding of the problem, and in practice. To a lesser extent, it is acceptable as a retrospective or laboratory. Further, an innovative experiment, already placed in external relations, requires an internal typology. It is appropriate to use paired features in it: sequential - parallel (synchronous), empirical (blind) - conceptual, etc. But he also has specific modifications, for example, the difference between clarifying and decisive signs. In addition, as part of the innovation process, an innovation experiment reproduces its varieties, for example, in the areas of activity (production, urban planning, education, mass communications, etc.), in terms of the content of innovation (managerial, technical, legal, etc.), by degree of radicalism, scale, etc.

The main thing is that an innovative experiment should answer the following questions: should this innovation be introduced, that is, move to a new introduction or not? If yes, then indicate what changes in the content of this innovation should be made before the innovation begins. And under what external conditions this innovation can be successfully implemented.

This interpretation of the essence.

It is necessary to combine the theory of experiment and the theory of innovation. Their merging or replacement from one to another is not required at all - each is an independent item. But now a qualitatively new moment of development has come for both, and their rapprochement is objectively predetermined. 
In terms of concepts, experiment and innovation partially coincide. Non-innovative experiments, as well as non-experimental innovations, are quite possible and necessary. But the whole point is in their "coinciding" volume, that is, the sphere of intersection. This sphere is growing. Especially, fast - with innovations. In the "mismatching" sector, there remain mainly non-radical innovations of the improving, developing order. And their number should decrease. An increasing number of innovations require a "transition mechanism", in which, along with the plan and forecast, an important function is performed by the experiment. And purely research experiments are increasingly raising the question of constructive conclusions, the use of their results for innovative purposes. Thus, rapprochement occurs from two sides.

The trend is obvious. With all the validity of the long-established definitions of an experiment as a research tool, we must nevertheless recognize their relevance to the pre-innovation period. Today, an innovative experiment is being put at the center of attention, which represents the diagnosis of innovation as a trial innovation. In this context, one of the main functions of the experiment becomes diagnostic.

The diagnostic function acts as an identification of the problems of innovation. Here we have in mind the assessment in two directions: the feasibility of innovation and its, viability. The first means determining the possibilities of adapting an innovation in the prevailing environment of its implementation, the possibility of implementing an innovation process; the second is the correspondence of the results of the innovation to the goals of a broader order for which the innovation is being designed. Estimates in these areas may diverge. The concepts of "feasibility" and "efficiency" in innovation are by no means identical: the quick and complete completion of an innovation does not exclude its negative effect on the system.

The diagnostic function of an innovative experiment also involves the development of innovation, i.e., determining the directions of its internal changes, both in content and in methods of its implementation. And these changes should ensure the feasibility of the innovation and its compliance with more general goals.

It is generally accepted that an experiment is divided into thought, branching into model and scenario, as well as real, which can be retrospective (passive) and active. In the latter, laboratory and field (field) are distinguished. An innovative experiment paired with the cognitive is possible in the forms of both mental and field. In the case of testing and introducing a new material or substance, it is acceptable as a retrospective or laboratory experiment. That's the case with the new substance CONTRRAST, its tests, implementation, the authors of the development, 
having all the positive test results, a bunch of certificates and awards, have been rummaging for several years. Commissions, competitions, exhibitions, conferences - and the cart is in place. There is no responsibility, there is no developer. Except the Chinese, who seek to receive everything as a gift. This is where the innovative experiment is needed, but who needs it, the authors. So far, nobody else. Therefore, to implement it is necessary to give.

Being part of the process, innovations, the innovation experiment reproduces its differentiation according to the areas of activity (production, urban planning, education, mass communications, etc.), according to the content of innovation (managerial, technical, legal, etc.), according to the degree of radicalism, scale, relevance, etc.

The innovation experiment will be the most developed, highest form of experimentation preceding implementation. It is he who is able to compose the moving part of the transition process mechanism when implementing innovations in modern conditions. The prospect of improving it is to improve the program, methodology, and psychological perception of it by people, which depends on the results that it will bring to them. And most importantly, the elimination of unscrupulous corruption schemes that accompany promising inventions and work. Experience shows that delaying the implementation, or even completely blocking and hiding effective innovative materials and technologies in the selfish, competitive interests is very common in practice. These are the discoveries and inventions of such geniuses as Nikola Tesla, D.I. Mendeleev, and many others in past, V.M. Glushkova, V.S. Leonov, V. Kondratov and others in our time. The authors of this development, too, were given the first-hand experience of testing the Energy Efficient Technologies for Accelerated Construction of Industrial and Civil Purpose Facilities, which gained recognition only sixth time with the enormous amount of implementation and economic effect (1 $240 \mathrm{mln}$ UAH). And the work on the corrosion protection of metal products and structures using Such a large-scale experiment and implementation could have been carried out at a powerful, not yet completely destroyed enterprise DBK-3 in Kiev and other enterprises of Golovkiyivskbud, where the interests of management coincided with the interests of the author's team of work. This fact provided material support for the development. But in cases where the authors of ideas get good results on the developed idea, but there is no support, then everything can go missing, up to favorable times or lucky events. Expectations for conferences, publications, exhibitions, etc. yes, but experience shows that they are rarely implemented. Here we need the interest of society and the state, the interest in the development of our own economy and production forces, the culture of production and, as a consequence, progress in the development and progress of social relations. 


\section{CONCLUSIONS}

On the basis of basic researches of corrosion mechanisms (including under the protective coating), methods of estimation of a condition and forecasting of corrosion resistance of metal-containing structures and possible terms of their failure and possible ways of prolongation of service life were created and implemented.

The newest technology of preparation of the corroded surface with the use of the Contrrust rust modifier (hi-tech technology), which currently has no world analogues, is proposed and introduced in the industry.

On the basis of the conducted researches the rational technology of surface preparation at drawing various types of paints and varnishes on metal structures of different technological purpose is developed.

According to the results of the research, it is established that the application of Contrrust and coatings based on bitumen-latex emulsions and other coatings of the developed composition of the surface do not require careful preparation before application (grade D).

Designs of coating systems for corrosion protection of oil and gas pipelines, valuable metal equipment, machines and other metal products are proposed. Studies and tests have shown that the proposed coating systems meet the required regulatory requirements to ensure long-term corrosion protection of metal products and can have great prospects, first of all, for the repair of existing facilities.

Methods for diagnostics, assessment and monitoring of the condition of metal structures and products developed and implemented at the state level (DSTU).

The overall economic impact of the implementation of the work is over UAH 60 million. including: Kyiv, str. Solomenska 2a, customer - Court of Appeal, economic impact - UAH 30.0 million; at Kutaisi-Abash gas pipelines (Georgia) - UAH 10.2 million, Lviv-Bobrivka - UAH 0.743 million, Brest (Belarus) - UAH 0.739 million, Karpatnaftokhim - UAH 6.41 million; Kharkiv, Sumy market - UAH 5.8 million; Temple, Kyiv, Michurina str. 64 981 thousand UAH, objects of the defense complex of Ukraine, including Zhytomyr BTZ, Shepetivska RE, Mykolayiv BP, and others.

Success can only be achieved with government support in the form of creating favorable conditions for the activities of organizations. The future leading position of any company, also a production one, is determined by the ability of leaders and all personnel to master high technology innovations, to generate and quickly implement their inventions and discoveries.

\section{SUMMARY}

Corrosion leads to billions of losses each year, consisting in putting down articles and machines made of metal, as well as the costs for the 
protection and restoration of metal products. Investigation of corrosion provides a basis to assert that the corrosion protection - is primarily a correct surface preparation and then a layer of high-quality sealants, paints or other types of coverage.

Solution "Contrrust" is a universal environmentally friendly plant-based anticorrosion agent $\theta$ turns rust to pure metal.

Environmentally friendly plant substance, patented and tested, with the name "CONTRRUST" is an effective means of blocking sources of corrosion (rust) and surface preparation for protective coatings.

The organization, led by leaders (owners, managers, performers), creating a genome (tradition) of high spiritual and business culture, organizing the synergistic interaction of the managing and controlled subsystems, formal and informal organizational structures of the organization with the mandatory support of the state, properly assess and promptly take into account internal and external factors are doomed to success.

\section{REFERENCES}

1. ТУУ 14333-082/001-98. Перетворювач іржі «КОНТРАСТ». Київ, 1998.

2. ДСТУ 4372: 2005. Перетворювач іржі на основі деревинної речовини. Технічні умови. [Чинний від 2005-02-28]. Київ, 2005. 16 с.

3. Перетворювач іржі «КОНТРАСТ» : пат. № (11) 61544. Технічний опис патенту № 61544.

4. Юхневич Р.Техника борьбы с коррозией / пер. с пол. ; Р. Юхневич, В. Богданович, Е Валашковский и др.; под ред. А.М. Сухотина. Ленинград : Химия, 1980. 224 с.

5. Розенфельд И.Л., Рубинштейн Ф.И., Жигалова К.А. Защита металлов от коррозии лакокрасочными покрытиями. Москва : Химия, 1987. $222 \mathrm{c}$.

6. Петров Л.Н. Коррозионно-механическое разрушение металлов и сплавов. Киев : Наукова думка, 1991. 215 с.

7. Забезпечення корозійної та функціональної стійкості металомістких комплексів і критичної інфраструктури за допомогою інноваційних науковомістких екоресурсозберігаючих технологій : монографія / В.І. Савенко, А.А. Плугін, І.В. Кущенко, Л.М. Висоцька та ін. Київ : УАН. Центр учбової літератури, 2019. 306 с.

8. Савенко В.І., Пальчик С.П., Клюєва В.В., Побєда С.С. Ентропія як прояв системної та діалектичної сутності будівельної організації комбінатного. Управління розвитком складних систем : збірник наукових праць. № 36. Київ : КНУБА, 2018. С. 142-147. URL: http://urss.knuba.edu. 
9. Савенко B.I., Доценко С.I., Клюєва В.В., Пальчик С.П. Генетичний підхід до ділової досконалості та ізоморфізм структури будівельної організації. 8 Міжнародна конф. КЗЯТПС ЧНТУ : тези доповідей. Чернігів, 2018. С. 101-102.

10. Савенко B.I., Доценко С.I., Клюєва В.В., Терещук М.О. Оптімальні методи управління будівельною організацією комбінатного типу. Управління розвитком складних систем : збірник наукових праць. № 35. Київ : КНУБА, 2018. С. 147-154. URL: http://urss.knuba.edu.

11. Савенко В.І., Клюєва В.В., Пальчик С.П. Оптимальні методи управлінської діяльності в будівельній організації комбінатного типу. Управління розвитком складних систем : збірник наукових праць. № 35. Київ : КНУБА, 2018. С. 147-154. URL: http://urss.knuba.edu.

12. Доценко C.I., Савенко В.I., Базиленко С.О., Клюєва В.В., Пальчик С.П. Інтелектуальні інформаційні технології у прийнятті ефективних рішень в управлінні підприємством. Управління розвитком складних систем : збірник наукових праць. №34. Київ : КНУБА, 2018. C. 161-169. URL: http://urss.knuba.edu.

Information about the authors: Savenko V. I., Candidate of Technical Sciences (PhD), Doctor of Technical Sciences (RF), Doctor of Civil Engineering, Professor, Kyiv National University of Construction and Architecture 31, Povitroflotskyi ave., Kyiv, 03037, Ukraine

Polosenko A. V., Graduate Student of the Kyiv National University of Construction and Architecture 31, Povitroflotskyi ave., Kyiv, 03037, Ukraine 